Meta

Journal des traducteurs

Translators' Journal

\title{
Abbreviation and Acronymy in English Arabic Translation
}

\section{Jamal al-Qinai}

Volume 52, numéro 2, juin 2007

URI : https://id.erudit.org/iderudit/016082ar

DOI : https://doi.org/10.7202/016082ar

Aller au sommaire du numéro

\section{Éditeur(s)}

Les Presses de l'Université de Montréal

ISSN

0026-0452 (imprimé)

1492-1421 (numérique)

Découvrir la revue

Citer cette note

al-Qinai, J. (2007). Abbreviation and Acronymy in English Arabic Translation. Meta, 52(2), 368-375. https://doi.org/10.7202/016082ar

\section{Résumé de l'article}

L'emploi d'abréviations et d'acronymes est un phénomène relativement rare et incompatible pour la morphologie de I'arabe. Les philologues arabes anciens ont préfère employer les mots dans leur inte-gralite. Cette pratique est conforme a la formation réservée des mots-valises et des abréviations dans la morphologie de I'arabe. Tandis que les acronymes sont encore rares en arabe moderne, la presence d'abréviations est généralement le résultat d'emprunts ou de formes étrangères transcrites. Malgré la rareté des acronymes dans les textes arabes anciens et modernes, ces abréviations ne represented aucun défi pour le traducteur arabe-anglais, qui s'intéresse a des questions d'équivalence et de similitude. Pour mieux comprendre la provenance et la diffusion de-telles formes, nous soulignerons plusieurs facteurs linguistiques et sociolinguistiques qui maximiseront la similitude entre le texte source et le texte cible.
Ce document est protégé par la loi sur le droit d'auteur. L’utilisation des services d’Érudit (y compris la reproduction) est assujettie à sa politique d'utilisation que vous pouvez consulter en ligne.

https://apropos.erudit.org/fr/usagers/politique-dutilisation/ 


\title{
BLOC-NOTES
}

\section{Abbreviation and Acronymy in English Arabic Translation}

\begin{abstract}
RÉSUMÉ
L'emploi d'abréviations et d'acronymes est un phénomène relativement rare et incompatible pour la morphologie de l'arabe. Les philologues arabes anciens ont préféré employer les mots dans leur intégralité. Cette pratique est conforme à la formation réservée des mots-valises et des abréviations dans la morphologie de l'arabe. Tandis que les acronymes sont encore rares en arabe moderne, la présence d'abréviations est généralement le résultat d'emprunts ou de formes étrangères transcrites. Malgré la rareté des acronymes dans les textes arabes anciens et modernes, ces abréviations ne représentent aucun défi pour le traducteur arabe-anglais, qui s'intéresse à des questions d'équivalence et de similitude. Pour mieux comprendre la provenance et la diffusion de telles formes, nous soulignerons plusieurs facteurs linguistiques et sociolinguistiques qui maximiseront la similitude entre le texte source et le texte cible.
\end{abstract}

\begin{abstract}
The use of abbreviations and acronyms is a relatively rare and inconsistent phenomenon in Arabic morphology. Ancient Arab philologists as well as those of late preferred using words in their entirety. This practice is consistent with the somewhat reserved formation of blends and abbreviated forms in Arabic morphology. While native acronyms are still rare in modern Arabic, the presence of abbreviated forms is by and large the outcome of loan-buzz words or transliterated foreign forms. Despite the rarity of acronyms in ancient and modern Arabic texts, these abbreviations represent no small challenge to the ArabicEnglish translator who is concerned with issues of equivalence and similarity. To better understand the provenance and dissemination of such forms we can point to several linguistic and sociolinguistic factors that will maximize the similarity between source and target text.
\end{abstract}

\section{MOTS-CLÉS/KEYWORDS}

diglossia and the cultural-technological gap, variant SL/TL forms, decapitalization, hybrid fusion and partial translation, epenthesis and breaking up of consonantal clusters

\section{Introduction}

The concomitant rush to grope for translations of scientific and technical terminology brought with it the thorny issue of how to introduce foreign abbreviations and acronyms. The latters are used to designate products, scientific processes and institutions for reasons of brevity or euphony. Copious borrowing of such forms reflects either the presence of a lexical gap or an attempt to acquire the air of prestige associated with western loans. The use of unassimilated loan acronyms marks one as literate, hence part of the elite who regard themselves as trendy and in fashion (Ngom 2000:164). There are, however, practical reasons for borrowing foreign acronyms based on the advantages of sharing a uniform code to refer to the same institutions, services, systems like ATS (Air Traffic Services), ECU (European Currency Unit) and TIF (transit international per fer) which are utilized in languages as diverse as English, Italian, French, Dutch or Danish (Gonzalez 1991: 163).

A large number of abbreviations and acronyms are readily adopted by Arabic dialects rather than the Classical version. Such foreign acronyms are often borrowed in their source language pronunciation without attempting to find possible equivalents through translation. In time, the dialectal adoption may find its way into Standard Arabic.

Furthermore, the somewhat high rate of illiteracy in the Arabic-speaking world may hamper the formation of native acronyms in view of the tendency among native speakers to make themselves comprehensible by avoiding opaque abbreviations. Since most advanced technology in the Arab world is imported from the West, the names and abbreviations are assigned by the countries of origin. Terms which name objects, gadgets or devices circulate in the form given by their makers such as LP (long-playing record), VHS (video home system) and acronyms with euphonic pronunciation as in Laser (light amplification by stimulated emission of radiation). Arabic speakers have no alternative but to accept the acronym or its transliterated approximant along with the purchased product. 
The transfer of acronyms from a source language to a target language of the same family is relatively predictable owing to the similarity of phonemes and word stems. However, when transfer is initiated between unrelated or remotely related languages, the magnitude of the problem is ever greater. To begin with, Arabic has far fewer abbreviations and acronyms than English or other European languages. In fact, acronymy is a new acquisition introduced by loan translation and transliteration. However, Blanchere (1956: 29, 46,144-149) postulates that abbreviations existed in the Quran as one may find in the opening verses of the following suras:

يس in Ya-sin, الم in al-Rum, طسم in al-Shu'araa'.

Issawi (1967: 118) finds that Arabic may very well translate European words or find native equivalents for them but rarely borrows them as they are. In terms of borrowing, Arabic ranks a very poor third after French and Italian.

Debate has centered on whether these newcomers should be left in their original form, modified by means of transliteration or partial translation, or eliminated altogether in favour of writing the full words of the abbreviation or the acronym. Analysis or decoding is initiated depending on the purpose of the translation, function, readership (e.g. a less educated TL audience) or when the transferred version is opaque (e.g. in the case of local acronyms such as MTC: Mobile Telecommunications Company 'in Kuwait'). In such cases, a descriptive paraphrase or the full words are used. In some cases, an acronym may be opaque even to native speakers. For instance, 'GI' (enlisted soldier in the US army) lacks any link to the sense of the full words 'General Issue' (Collins: 612) and, therefore, cannot be explicated when transferred into Arabic. Newmark (1988:201) cites RPR as an example of an acronym which is known by its function as 'the true Gaulist party' rather than by what it stands for 'Rassemblement Pour la République.' Again, it is mandatory that such terms be transliterated rather than translated into Arabic.

In time, even opaque acronyms may gain international acceptance and become naturalized in their transliterated form (e.g. OPEC, FAO, and NASA...). Nevertheless, some languages like Arabic resist most acronyms and explicate them (Newmark 1988: 200).

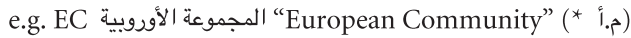

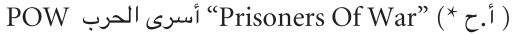

\section{The Inconsistency of the Process}

Unlike most Indo-European languages, Arabic, as a member of the Semitic family has only a handful of native abbreviations (mostly blends) and acronyms. The majority of these forms denote recurrent phrases of habitual usage rather than the initials of proper names or nouns.

e.g.

بسم الله الرحمن الرحيم to utter بسمل [In the Name of Allah the Compassionate the Merciful]

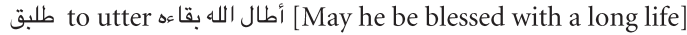

to utter الحمد لله رب العالمين ألهاء [Praise be to Allah]

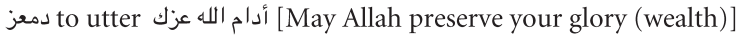

[Come to prayer]

[May peace be upon him]

Most contemporary abbreviated forms are the outcome of imitating translations from other languages. The noticeable receptiveness towards borrowing from foreign sources may be understood given the lack of native acronyms and blends in Arabic. The arbitrariness of forming abbreviations in modern Arabic is attested to by the fact that while we may have Arabic equivalents or transliterated versions of certain foreign abbreviations, other closely related abbreviations are spelled out owing to the absence of Arabic translated or transliterated equivalents.

e.g.

Acc. (accountant) $\rightarrow$ م. (محاسب)

Dr. (Doctor) $\rightarrow$ د. (دكتو)

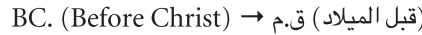

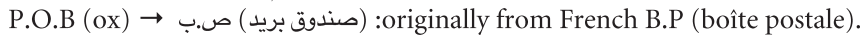

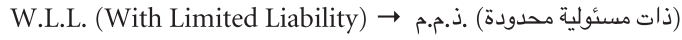

cm. (centimeter) $\rightarrow$ سنتيميتر) 
Etc. $\rightarrow$ (إلى آخره)

KG (Kilogram) $\rightarrow$ كجم (كيلوجرام)

It should be noted that the Arabic acronyms كجم anclude other letters than the initials i إلخ إ ז. respectively.

Yet, the following abbreviations are rendered in full:

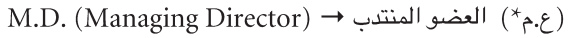

MP (Member of Parliament) $\rightarrow$ (ع. )

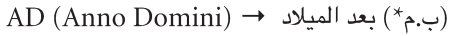

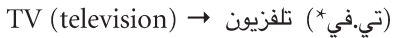

HP (horse power) $\rightarrow$ (مصان (ميكانيكي)

ICU (intensive care unit) $\rightarrow$ وحوة العناية المركان

The reverse process occurs in the case of the English clipping Prof. (professor) $\rightarrow$ الأستاذ الدكتور) أ.د. when used as an academic rank within a university context to set it apart from the rank of an associate professor or an assistant professor. Nevertheless, the full word is restored البروفيسور in non-academic contexts.

The transliterated or/and the translated equivalents of some acronyms are used randomly with no preset rules. A case in point is DNA (desoxyribonucleic acid) which until recently was transliterated as

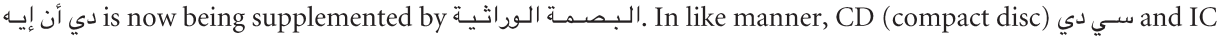

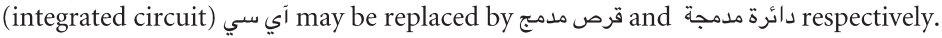

Finally, a native Arabic speaker encounters many transliterated loan acronyms with phonemes that constitute the initials of their native SL words. S/he finds no link between these acronyms and the initials of the full words in Arabic. A case in point is the acronym "WHO" (World Health Organization) which is transliterated into Arabic as (identical with the 3rd person sing. pronoun) while the acronym of

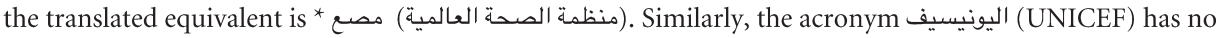
correspondence with the initials of (صطتأم *) الطفولة التابع للأمم المتحدة صندوق). The rule, here, can be summed up in the words of Newmark,"unless they (i.e. abbreviations) coincide, they are written out in the TL" (Newmark 1988: 145).

\section{Variant SL/TL forms and anomalies}

Arabic borrows acronyms from variant language sources such as English, French, Italian, Spanish... etc. For instance, in former French colonies of North Africa and East of the Mediterranean, there is a high rate of lexical borrowing from French through local dialects and ultimately into standard Arabic. In contrast, English loans assumed primacy in other parts of the Arab world along with other Turkish, Italian, Persian and Indian influences. Consequently, a translator finds himself baffled by the multitude of acronyms for one and the same referent. What is BIT in French is IAA in German and ILO (International Labour Organization) in English, the latter being the most prevalent of the three. Likewise, EWG in German is EEC in English and MAOI (monoamine oxides inhibitors) becomes IMAO in French (Newmark 1988: 148).

When SL acronyms designate important bodies and when the underlying phrases are widely known in the TL language, a native equivalent is used instead (e.g. ARE for Arab Republic of Egypt is rendered ع.P.๕.). On the contrary, when one deals with less popular acronyms in the TL locale, international communication often favours the adoption of the original acronym (English or French, predominantly) as a kind of common code (e.g. KGB, GATT, FBI, RAF) (Gonzalez 1991: 161).

One normally expects the adoption of a single acronym to refer to a given concept or organization either through the clustering of the initials of its equivalent SL paraphrase or through the direct borrowing of the TL form (e.g. LP, VHS as borrowed from English). In practice, however, inconsistencies of double terminology abound owing to phonotactic or syllabic constraints, euphony and degree of similarity between the acronym and TL common words (IbId).

The situation is further aggravated by the fact that Arabic borrows acronyms from variant language sources such as English, French, Italian, Spanish...etc. For instance, in former French colonies of North Africa and East of the Mediterranean, there is a high rate of lexical borrowing from French through local dialects and ultimately into standard Arabic. In contrast, English loans assumed primacy in other parts of the Arab world along with other Turkish, Italian, Persian and Indian influences. Consequently, a translator finds himself baffled by the multitude of acronyms for one and the same referent. What is BIT in French is IAA in German and ILO (International Labour Organization) in English, the latter being the most 
prevalent of the three. Likewise, EWG in German is EEC in English and MAOI (monoamine oxidase inhibitors) becomes IMAO in French (Newmark 1988: 148) and what is commonly known as AIDS is SIDA (from French) in Lebanon, Syria, Algeria, Morocco and Tunisia. Nevertheless, this diversity of acronyms is bound to change in the face of the constant growth of English as the lingua franca in the third millennium.

In addition, some foreign acronyms exhibit anomalies, which may pose problems of identification with the SL words. According to a recent ISO publication, there is a lack of correspondence between the official title when used in full International Organization for Standardization and the short form ISO. Shouldn't the acronym be IOS ? In fact, ISO is a word derived from the Greek isos meaning 'equal' which is the root of the prefix 'iso-' as in 'isometric' i.e. 'of equal measure' (ISO 1994: 3)

To muddle the situation further, ISO does not correspond to the official title of the organization in French 'Organization Internationale de Normalisation.' Finally, the acronym itself is given varying pronunciations in Arabic:

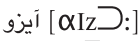

$$
\begin{aligned}
& \text { [I:Zつ:] } \\
& \text { [I:SD:] }
\end{aligned}
$$

In a few cases a shortened form rather than an acronym is coined for its euphonic features and is readily diffused through the media. A case in point is Interpol إنتربول, an international abbreviation, which is more commonly used than its respective acronym in French OIPC (Organization Internationale de la Police Criminelle) or English ICPO (International Criminal Police Organization). Similarly, HABITAT is considered more evocative than UNCHS for United Nations Conference on Human Settlements (Gonzalez 1991: 161-2).

\section{Translation vs transliteration}

The arbitrary nature of Arabic renditions of abbreviations is manifest in the use of TL multi-equivalents for a given SL term. A given abbreviated form may at one time be printed in Arabic script and is integrated into the fabric of the sentence like any other word while its Arabic equivalent is placed in parenthesis or quotes with or without the word for 'i.e.' أو or the word for 'or'

e.g.

AWAX spotted the aircrafts قامت طائرات الأواكس (المراقبة الرادارية الجوية) برصد الطائرات

At times, the transliterated word is placed in parenthesis or quotes adjacent to the Arabic equivalent

$$
\text { قامت طائرات المراقبة الرادارية الجوية 'الأواكس' / (الأواكس) برصد الطائرات }
$$

This practice prevails even in the case of Arab-based organizations.

e.g.

ALECSO (Arab League Educational, Cultural and Scientific Organization)

معتثع * instead of forming a native acronym المنظمة العربية للتربية والثقافة والعلوم (الألكسو)

AOPEC (Arab Organization for Petroleum Exporting Countries)

مأعمن * منظمة الأقطار العربية المصدرة للنفط (الأوابك )

Occasionally, translators may use a shortened form from the key words of the SL original and use it with or without the transliterated form. However, the abbreviated gloss does not lead to coining a new acronym.

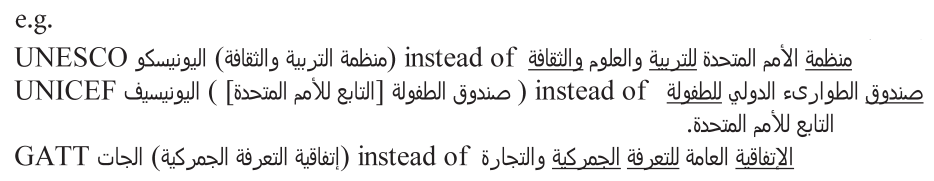

It should be noted that a transliterated acronym rather than the full word version may be naturalized in Arabic to serve as a stem for further derivation. 
e.g.

From 'laser' ليزر :

لزَز 'to use laser'

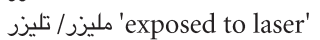

ملزار 'laser appliance' (1985:29 ملتيز التربية العربي 'ملزر

\section{Decapitalization}

Arabic uses lower case letters in writing native words as well as foreign loan forms. SL acronyms are decapitalized in Arabic, thus rendering them similar in form to other common nouns (or verbs). It is therefore hard to distinguish between a common word and an acronym (native or transliterated) without enclosing marks or parentheses. The reader relies on his general knowledge and linguistic intuition in guessing whether a word is a proper noun or not.

e.g.

The Arab League $\rightarrow$ جدع:* an Egyptian colloquial for a shrewd or witty fellow).

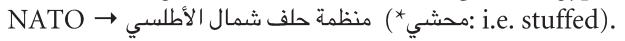

TUC (Trade Unions Congress- Britain) $\rightarrow\left({ }^{*}{ }^{*}\right.$ : من :

PM (Police Magistrate) $\rightarrow($ * $:$ hay, straw).

Further, some abbreviations may stand for several different referents. The only means of discrimination is by employing capital letters.

e.g.

PM (Prime Minister/ Post Master/ Provost Marshal).

p.m. (post meridian).

Similarly, the difference between 'cb' (columbium) and 'CB' (Citizen's Band) which depends on capitalization is nullified in the Arabic transliteration ســــ Likewise, 'cm' (centimetre) and Cm (the chemical symbol for curium) are rendered identical in the Arabic equivalent سم ' unless the initials are separated by dots س.م.

Even in the case of native Arabic abbreviations, there is no means of distinction as all letters have a uniform case.

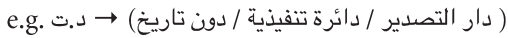

[Literally: n.d. $\rightarrow$ no date /E.D $\rightarrow$ Executive Department /E. H. $\rightarrow$ Export House]

The possible confusion between the abbreviated form and a common noun owing to the absence of capitalization may thus account for the reserved use of native acronyms in Arabic. Consequently, native speakers of Arabic avoid pronouncing acronyms as single words in favour of dissecting them into separate initials as they do with abbreviations. This segmental unpacking may be realized in writing by inserting stops between the initials of the acronym.

\section{Linguistic Modification}

Some loan acronyms have existed in Arabic for so long that they have become fully naturalized and integrated in the linguistic competence of monolingual speakers. The integration or naturalization process mainly consists of:

1. The substitution of the closest Arabic sounds for foreign sound units that do not exist in Arabic phonological repertoire:

A major problem of adopting acronyms concerns the representation of their original pronunciation within the framework of the Arabic script. A loan acronym may be respelled in parenthesis in approximation to its native form. This method, however, is fraught with significant changes.

The absence of foreign sounds such as p/p/, j/3/, g/g/, ch/č/, v/v/, along with vowels such as /o/, /e/, $/ æ /, / \partial: /, / œ /, / \varepsilon /$ would lead to a modification in the acronym's transliteration or pronunciation. Likewise, owing to the tendency of some modern writers, the Arabic script is written without the superscript diacritics which stand for short vowels namely fathah /O/, dammah / U/ and kasrah /I/.In effect, short SL vowels are often replaced by their long TL counterparts which are represented by proper vowel characters ( $/ \partial: /$, g/U:/, ـ / I:/). 


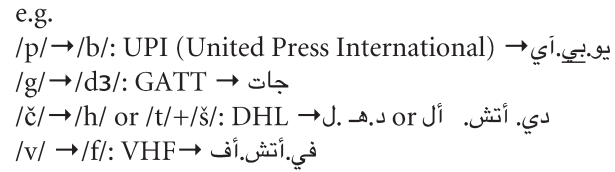

In order to compensate for the tendency of ignoring superscript diacritics for short vowels, translators may insert the nearest long vowel which gives rise to a change of pronunciation.

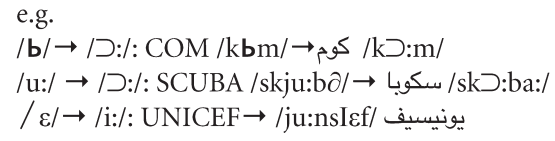

Likewise, SL diphthongs may be monophthongized and are often rendered into Arabic letters by approximation (Aziz: 75).

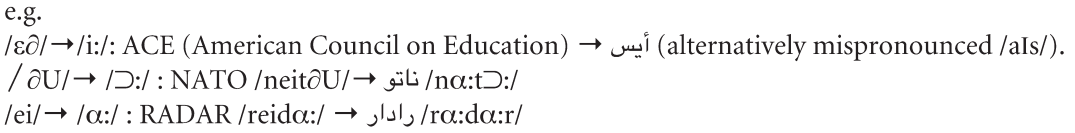

Some changes, however, can be ascribed to mispronunciation or bad transliteration practice on the part of either the translator or the initial user who introduced the acronym into Arabic. A case in point is the acronym AIDS which has four possible transliterations with varying phonetic pronunciations of the phoneme /ai/ owing to the non-insertion of short vowel diacritics.

$$
\begin{aligned}
& \text { إيدز ['I:dz] } \\
& \text { [ايدز [aydIz] } \\
& \text { آيدز [a:ydz] } \\
& \text { آيدز [a:ydz] }
\end{aligned}
$$

It should be noted, however, that a reverse process i.e. denaturalization of assimilated acronyms may be regarded as an index of high social status. Thus, educated Arabic speakers may copy the original pronunciation of the SL acronym to the disfavour of the TL incorporated pronunciation (Ngom: 165).

e.g.

Knet (Kuwait Network): previously transliterated كي نت and mispronounced

/ki: net/ due to the absence of superscript diacritics. Now it is correctly pronounced /keI net/.

2. Hybrid Fusion (especially in chemical acronyms):

There are instances where a given acronym is partially translated next to the SL initials

e.g. F.Z.S. (Fellow of the Zoological Society) F.Z.S..زميل جمعية

This would deprive the acronym of its brevity a matter that renders a full translation more convenient owing to the repetition of both the SL initials and the full words.

In the following chemical abbreviations, Arabic spells out the words in full. Some words are (partially) translated or transliterated while superscript numbers are given their full ordinal equivalents in Arabic.

e.g.

ثاني كبريت الصوديوم Sa

Sالث كبريت الصوديوم الصودم (Trisulfure de Sodium)

Even when a direct transliteration is attempted, the Arabic version would involve more than simply the graphological correspondents owing to the pronunciation of each SL symbol.

e.g.

S4O H² (Acide Sulfurique) $\rightarrow$ r حمض الكبريت) اسع أو اتش)

Graphologically, there is a lack of correspondence between Arabic characters and the English consonants of 'c','g', 'v','h' as well as most vowels and diphthongs. 
Therefore, any direct graphological transfer would lead to mismatches e.g. 'h' $\rightarrow \rightarrow$, 'v' $\rightarrow$, 'I' I). For instance, the abbreviation FBI, commonly transliterated أ ف. بي.آي would change significantly if ren-

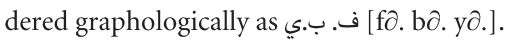

For the same reason, Hb. for " hemoglobin" is ignored in translation in favor of the transliterated word هيموجلوبين .

3. Epenthesis and breaking up of foreign consonantal clusters to meet Arabic phonotactic constraints:

Arabic speakers tend to avoid consonantal clusters by breaking them up through inserting short vowels. Thus, a CCCV cluster may be modified into CCVCV in Arabic. This has the effect of altering the pronunciation of the original acronym.

e.g.

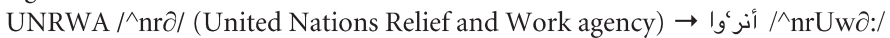

KISR /kIsr/ (Kuwait Institute for Scientific Research) $\rightarrow$ كسنر /kIs $\partial$ r/

4. Breaking up of the compound components of acronyms:

While most Indo-European and Romance languages form acronyms from the initials of compounds, Arabic tends to spell out the acronym by breaking up compounds into individual words separated by spaces.

e.g.

NASA (National Aeronautics and Space Administration) الإدارة القومية للملاحة الجوية والفضاء

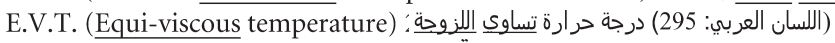

Thus while an English acronym is composed of the initials of two compounds, an Arabic equivalent may consist of the initials of all the components of the compound word.

\section{A note on Clipping}

As with abbreviations and acronyms, Arabic does not freely admit clipped forms. Rather, the full word is substituted for foreign clippings.

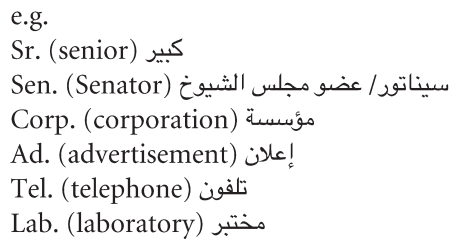

However, as the scope of this paper is mainly focused on abbreviations and acronyms, we recommend further investigation of clipping and blending in future studies. Of particular interest would be the morphophonemic changes of such forms upon their assimilation into Arabic.

\section{Conclusion}

The examples cited in this study give a glimpse of the difficulties that await the translator when dealing with acronyms and abbreviations of foreign sources. The translation or borrowing of acronyms is conditioned by various factors such as euphony, semantic transparency and domain.

At present, inconsistency seems to be the rule in transliterating abbreviations and acronyms into Arabic. In view of the inherent linguistic problems such as the absence of capitalization and the lack of correspondence between some Arabic and foreign consonantal and vowel segments, it is proposed that acronyms be marked in the following manner:

1. In order to make up for the absence of capitalization, an abbreviation or acronym may be enclosed in parentheses or inverted commas, written in italics or boldface or even underlined. As the acronym gradually gains ground into the language, these distinguishing marks are left out.

2. While the transliteration of an acronym is a convenient means of avoiding the excessive repetition of the spelled out components of a given acronym, it is advisable to use the Latin characters of the original in order to ensure accurate pronunciation and skirt any problems of confusing the acronym with a common word. 
3. In case of frequent reference to a given acronym within the same text, it is important to establish a short form either by introducing an Arabic transliteration or selecting key words for repetition throughout the text.

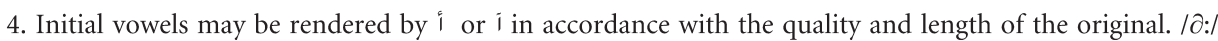
and $/ \supset: /$ are to be transliterated ' $ـ$ and ', respectively. Final / $/ \partial /$ and /a/ may be transliterated $₫$ and I (alif) respectively (Aziz; 81).

5. Foreign consonants may be given modified characters adopted from Urdu or Persian.

$$
\begin{aligned}
& \text { e.g. } \\
& / \mathrm{p} / \rightarrow \\
& / \text { č/ } \rightarrow \text { 区 } \\
& \text { /g/ } \rightarrow \text { } \\
& \text { / } / \mathrm{v} / \rightarrow
\end{aligned}
$$

\section{REFERENCES}

\section{English}

Algeo, J. (1975): “The Acronym and its Congener", in Makкı, A. and V. B. Maкki (eds) The First Lacus Forum, Columbia, Hornbeam Press.

Azız, Y.(1983): “Transliteration of English proper nouns into Arabic”, Meta 28-1, p. 70-84.

Blanchere, R. (1956): Introduction au Coran, Paris.

Collins English Dictionary (1985): Glasgow, Collins.

Gonzalez, F. R. (1991): “Translation and Borrowing of Acronyms: Main Trends", International Review of Applied Linguistics in Language Teaching 29-2, p. 161-170.

International Organization for Standardization (ISO) (1994): 2nd edition, Geneva, Compatible Technology Worldwide.

Issawi, C. (1967): "European Loan-words in Contemporary Arabic: A Case Study in Modernization", Middle Eastern Studies, p. 118

Newmark, P. (1988): A Textbook of Translation, New York, Prentice Hall.

Ngom, F. (2000): "Sociolinguistic Motivations of Lexical Borrowings in Senegal", Studies in the Linguistic Sciences 30-2, p. 159-172.

Arabic

مكتب تتسيق التعريب.اللسان العربي (1983).العدد 21. الرباط. المغرب.

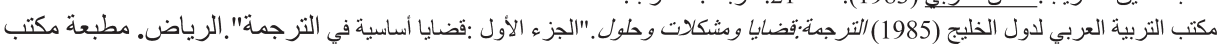
التربية العربي. 